\title{
LEGAL DIMENSIONS OF BRITISH ENTRY INTO THE EUROPEAN COMMUNITY
}

\author{
WerNer FeLd* \\ INTRODUCTION
}

During a speech in Brussels in May, r970, commemorating the twentieth anniversary of the Schuman Plan, the President of the Court of Justice of the European Communities, Robert Lecourt, declared that the country which becomes a member of the Community "marries its law." With Britain's membership impending, the question obviously needs to be posed, what kind of a marriage will it be? The purpose of this paper is to examine the legal aspects and implications arising from the entry of the United Kingdom into the European Community. In particular, it will focus on the legal basis and effects of the accession treaty, the impact of Community law on the British legal system and judicial procedures, and the possible influence of common law practices on the judicial functions of the Court of Justice of the European Communities.

In view of the complexity of some of the legal and constitutional issues involved, this study is largely preliminary in nature, seeking to identify major problems and perhaps raising questions for intensive research. Practical experience gathered from the gradual fusion of Britain into the European Community will undoubtedly be an invaluable an'd essential contribution to answers to some of these questions.

\section{I}

\section{The Accession Agreement}

\section{A. Accession Procedure}

Admission to full membership in the European Community is governed by Article 237 of the European Economic Community (EEC) Treaty (popularly referred to as the Rome Treaty), Article 205 of the European Atomic Energy Community (Euratom) Treaty, and Article 98 of the European Coal and Steel Community (ECSC) Treaty. All three treaties stipulate that any European state may apply for membership in the Community, but the term "European state" is not to be construed in too narrow a geographic sense. As a consequence, Turkey is considered to be a European state, although the greater part of its territory is located in Asia. On the other hand, Israel cannot be regarded as European because it lacks any geographic connection with Europe, although much of its population has European roots. ${ }^{1}$

Additional conditions for admission flow from the preamble of the EEC Treaty

- Department of Political Science, Louisiana State University in New Orleans.

${ }^{1}$ Cf. Comments to Article 237, in Wohlfarth, Everling, Glaesner \& Sprung, Die Europaïsche WIRTSCHAFTS GEMEINSCHAFT (I960). 
which stresses the ideals of peace and liberty and the objectives of "an ever closer union among the European peoples." As a consequence, applicant countries must be dedicated to the principles of democracy and political equilibrium and must accept the objective of eventual political unity in Europe. Since the enhancement of the economic development of the Community is also an avowed goal of the member states, applicants for accession must be able to make positive contributions to this objective. This means that their level of economic strength and growth must be comparable to that of the current members. This condition has eliminated from membership, at least for the time being, countries like Greece and Turkey which have had to content themselves with associate status until their economic level can be raised sufficiently to qualify as full members of the Community.

The procedure for accession requires that an application be addressed to the Council of Ministers, which is to act by unanimous vote after obtaining the opinion of the Commission. No consultation of the European Parliament is necessary, but the Council and Commission can avail themselves of such consultation if they deem it advisable. On the basis of a favorable decision by the Council, negotiations between the member states and the applicant are to be conducted to determine the conditions of admission and the necessary adaptation of the Treaty to the new situation. For example, the distribution of weighted votes among the member states in the Council of Ministers has to be altered to reflect the increased membership. Similar changes must also be made for the European Parliament, the Economic and Social Committee, the annual contribution to the Common Market budget, the Social Fund, and the European Investment Bank. ${ }^{3}$ The size of the Community institutions may also have to be reconsidered to ensure equitable representation of the prospective member or members. ${ }^{4}$

Under the provisions of the EEC and Euratom Treaties the accession agreement requires ratification by the Community member states and the applicant country in accordance with their respective constitutional rules. Under the ECSC Treaty (art. 98) the accession agreement becomes final for the member states by the appropriate decision of the Council of Ministers which then must be accepted by the

\footnotetext{
2 These standards were applied to the British membership application in: Commission of the European Communities, Opinion Submitted to the Council Concerning the Applications for Membership from the United Kingdom, Ireland, Denmark and Norway, Buld. of THE EuR. Comsunities, Sept./Oct. 1969, at Supp. Cf. J. Raux, LEs Relations exterérieures de la CoMmunauté economique europétene 463-83 (1966). Raux's list of conditions is somewhat longer.

8 Treaty Establishing the European Economic Community, March 25, 1957, CCH CoMM. MkT. REp. I I-5449, 298 U.N.T.S. I4-94 [hereinafter cited as EEC Treaty, art. -], arts. 148, 138, 194, 200, 203; Protocol to the EEC Treaty; Protocol on the Statute of the European Investment Bank, March 25, 1957, CCH CoMar. MKT. REP. I4II5, 298 U.N.T.S. I20-13I, art. 4. The provisions of the ECSC Treaty for accession are somewhat different from those of the EEC Treaty, whereas the Euratom Treaty provisions are identical to those of the EEC Treaty. Cf. Treaty establishing the European Atomic Energy Community (Euratom), March 25, 1957, 298 U.N.T.S. x69-266; Treaty Instituting the European Coal and Steel Community, April I8, I95I, 26I U.N.T.S. I40-319 [hereinafter cited as ECSC Treaty], arts. 98 , roo.

'Cf. comments to Article 237 in II A. Campbeis, Common Market Law i6i (rg69).
} 
applicant country following its constitutional procedure. The accession becomes effective with the deposition of the ratification instruments. ${ }^{5}$

Admission to membership carries with it by definition the assumption of rights and obligations equal to those of the original member states and acceptance of decisions and policies made since the Community treaties came into force. Nevertheless, for a limited period the accession agreement may permit a differential trearment for the new member in order to ensure an orderly transition in such critical fields as the elimination of internal tariffs, adjustment to the common' external tariff of the Community, agriculture, and the contribution to the Community budget. However, the eventual full assumption of rights and obligations under the Community treaties is imperative and it is for this reason that neutral states such as Austria have been reluctant to petition for admission and have preferred to seek associate status. ${ }^{\mathbf{B}}$

After the first attempt of Britain to join the Community was aborted by General de Gaulle's veto in January 1963 , the British Government reactivated its application for membership in 1967 . After several years of sparring and bargaining the negotiations culminated in the signing of the accession' agreement on January 22, 1972, in Brussels. The effective date for accession of the United Kingdom and the three other applicant countries, Ireland, Denmark, and Norway, has been set for January I, I973, provided that the ratification procedures are completed and the ratification instruments deposited by December 3I, I972. ${ }^{7}$

\section{B. Modifications in the Community System}

The accession has important legal effects and implications for both the Community system and Great Britain. In the Community the composition of the decison-making organs and the distribution of voting rights will change beginning with $x 973$ to reflect the participation of the four new member states. The number of Commission members will be increased from nine to fourteen with two positions allotted to Britain. The European Parliament will be enlarged from I42 to 208 and Britain will have the same number of delegates (36) as France, Germany, and Italy. The Economic and Social Committee of the EEC will also be expanded from Ior to I55. The Court of Justice, hitherto composed of seven judges and two advocates-general, will have eleven judges and three advocates-general. Seven judges will be required for the court sitting in plenary session. It is anticipated that Britain will be allocated either two judgeships or one judgeship and one position for advocate-general. Other institutions such as the European Investment Bank will have their various organs expanded; and various committees, for example, the ECSC Consultation Committee, will be enlarged.8

\footnotetext{
"For EEC and Euratom accessions, the ratification documents are to be deposited with the Italian Government in Rome; for ECSC accession, with the French Government in Paris.

${ }^{\circ}$ EEC Treaty, art. 238. For a full discussion of the instrument of association, see Feld, The Association Agreements of the European Communities: A Comparative Analysis, Ig INr'工 Organization 223 (1965).

${ }^{7}$ Daily Bull., Jan. 2I-23, I972 (Europe: Agence Internationale d'Informtation Pour la Presse). In Ireland, Denmark and Norway referenda are required for the ratification procedures.

${ }^{8}$ Europe, Agence Internationale d'Information Pour la Presse, Doc. No. 661, Jan. 21, I972.
} 
The Council of Ministers, in which each member country has one representative, will consist of ten ministers. The new voting rights will be ten for France, Germany, Italy, and the United Kingdom, five for Belgium and the Netherlands, three for Denmark, Norway, and Ireland, and two for Luxembourg. These voting rights are important when decisions of the Council need to be taken by a qualified majority. In cases of Council decisions to be taken on the basis of Commission proposals, favorable action will require forty-three voting rights. When Council decisions are envisaged without Commission proposals, the forty-three necessary votes must represent at least six member states. A simple majority may be obtained by a favorable vote of six states. ${ }^{9}$

\section{Problems of British Ratification}

For Great Britain the accession agreement entails the obligation, discussed earlier, to accept the three Community treaties and all subsequent Community legislation adopted under these treaties. However, a transition period of generally five years has been granted during which British industry, commerce, and agriculture are to adapt themselves to the elimination of tariffs, non-tariff barriers, the common external tariff, and the complex rules of the Common Agricultural Policy (CAP). The rates of financial contributions to the Community budget and the European Investment Bank are also spread out over five years and will generally reach their full amount on January $I, 1978 .^{10}$

For Britain's trade relations with the developing countries of the Commonwealth, the status quo will be maintained until December $3^{r}$, 1975. During this period some of these countries may seek association agreements with the enlarged Community or look for other solutions for their international trade problems and aspirations. The dependent territories of Britain are scheduled to associate with the Community in accordance with the provisions of Articles $13 I-I 36$ of the EEC Treaty and will thereby be placed in the same position as the dependent territories of France and the Netherlands. ${ }^{11}$

Ratification of the accession agreement under British constitutional practice lacks the explicit rules of most written constitutions of the Continent and elsewhere which, through the involvement of the parliamentary machinery in the ratifying process, can bestow immediate legislative effect on many provisions of a treaty. Since in Great Britain foreign affairs are con'ducted basically on behalf of the Crown by her or his Majesty's ministers as part of the royal prerogative, the negotiation and ratification of treaties can be performed theoretically without consultation of Parliament. However, if the rights of citizen's should be impaired or obligations

\footnotetext{
${ }^{9}$ Id. Cf. EEC Treaty, art. 148; Euratom Treaty, supra note 3, art. xI8. See also ECSC Treaty, art. 95 , the so-called small treaty revision clause. It presently requires a $5 / 6$ majority which will be increased to $9 /$ ro of the member states.

${ }^{10}$ Europe, Agence Internationale d'Information Pour la Presse, Doc. No. 661, supra note 8. However, some ceilings are set for these contributions under certain conditions until 1980 .

${ }^{11}$ Id.
} 
imposed on them by self-executing clauses of a treaty, the consent of Parliament must be sought. Moreover, no financial commitment contained in a treaty can be undertaken without the approbation of both houses of Parliament. Therefore, in practice, the powers of the Crown in ratifying treaties are limited and legislation has to be introduced and passed by Parliament to give those parts of a treaty that affect private rights the force of law. Moreover, treaties which for their execution and application in the United Kingdom require some addition or modification of existing law require specific legislative action by Parliament. ${ }^{12}$

It is obvious that the accession agreement qualifies in every respect for necessary legislation to achieve ratification. The full acceptance of the Community treaties with their considerable number of self-executing clauses-for example Article I2 of the EEC Treaty: prohibition of reintroduction of internal tariffs ${ }^{13}$-and the large number of subsequent ordinances directly binding on private persons and corporations in Britain makes parliamentary action imperative. ${ }^{14}$ The same applies to the extensive financial contributions to the Community budget and the European Investment for which the British government has obligated itself. Finally, a legislative basis must be constructed for the harmonization of fiscal and economic laws to bring the British system in line with the legal harmonization measures accomplished so far by its Community partners. ${ }^{15}$

The British government, of course, has been fully aware of this situation. In Ig6r, parliamentary approval for the commencement of the negotiations was obtained although both the House of Commons and the House of Lords stipulated that no final agreement could be accepted without the consent of both houses. A similar sequence was followed in the negotiations leading to the signing of the accession treaty of 1972. After the major issues involved in British entry had been elaborated and a fundamental position agreed upon, Parliament was invited to make a decision of principle on whether the arrangements negotiated were satisfactory and whether Britain should proceed to join the Community. The House of Commons gave its approval on October 28, I97x, followed by favorable action in the House of Lords. Three days after the signing of the accession agreement on January 22, the European Communities Bill was formally presented to the House of Commons. Its adoption would authorize the United Kingdom to join the three Communities and the legislation embodied in the bill would create a legal situation which would take

\footnotetext{
${ }^{12}$ Cf. E. Wade \& G. Phillips, Constitumonal Law 274-76 (7th ed. I965).

${ }^{13}$ See Stein \& Hay, Legal Remedies of Enterprises in the European Economic Community, 9 Ax. J. Comp. L. 375, 400-0I (Ig60).

${ }^{14}$ See EEC Treaty, art. 189: "For the achievement of their aims and under the conditions provided for in this Treaty, the Council and the Commission shall adopt regulations and directives, make decisions and formulate recommendations or opinions.

Regulations shall have a general application. They shall be binding in every respect and directly applicable in each Member State.

Directives shall bind any Member State to which they are addressed, as to the result to be achieved, while leaving to domestic agencies a competence as to form and means."

${ }^{10}$ Cf. EEC Treaty, arts. I00-102.
} 
into account all contingencies arising from the full acceptance of the Community treaties. ${ }^{16}$ Despite strong opposition to the bill by Labor Party and Conservative antimarketeers who introduced a number of crippling amendments designed to assure more extensive parliamentary control over Community affairs, the Heath Government prevailed and the amendments were rejected although the Government majority at times dropped to agonizingly low margins (four in one case). ${ }^{17}$ The specific provisions of this bill will be discussed later.

\section{The Accession Agreement and the Sovereignty of Parliament}

The doctrine of the legal sovereignty of Parliament postulates that no written constitution or any constitutional document can impair the legislative ability of the House of Commons and the House of Lords. Moreover, as each Parliament is sovereign, it cannot bind its successor and every law, even if its nature is essentially constitutional, can be repealed later by a simple Act of Parliamen't. ${ }^{18}$

If one were to accept the doctrine of legal sovereignty of Parliament in this sweeping form, legislative approval of the accession agreement today could be modified tomorrow and such action could also be taken by the next Parliament. Some students of British constitutional law have argued that there are indeed limitations to the doctrine of legal sovereignty. ${ }^{19}$ One limitation is claimed to lie in the Acts of Union of ${ }^{7} 707$ which involved a transfer of legislative power coupled with the imposition of some restrictions on the new Parliament when the parliamentary union between England and Scotland was established. Another limitation, according to Mitchell, may be effected by self-imposition and the example given is the Statute of Westminster of I93I and the subsequent Independence Acts enjoining the

\footnotetext{
${ }^{16}$ For details of the accession agreement and the proposed legislation see Treaty Concernino the Accession of the Kingdom of Denmark, Ireland, the Kingdom of Norway aNd the United Kingdom of Great Britain and Northern Ireland to the European Economic Community and the Eunopean Atome Energy Commontty and Decision of the Council of the European Communities Concernino the Accession of the Said States to the European Conl and Steel Community, Cand. No. 4862, :reprinted in part in The Times (London), January 27, 1972, at 6, col. x. Special provisions are contained in this bill for the implementation of the Community treaties by the legislatures of Northern Ireland, tho Channel Islands, the Island of Man, and Gibralter (cl. 2).

${ }^{17}$ The Times (London), Feb. 19, 1972, at 13 , col. I; Mar. 6, 1972, at I4, col. 3; Mar. 14, 1972, at I4, col. I; Mar. 30, I972, at I6, col. I; Apr. I9, I972, at I2, col. 4; Apr. 20, 1972, at 3, col. x; May 3, 1972, at $I$, col. 6, at I4, col. 5; June 9, 1972, at 5, col. I, at 10, col. 6, at I4, col. I; June I5, I972, at I, col. 7 , at 2 , col. $x$, at 4 , col. 7 , at 5 , col. 1 , at 16 , col. 5 ; June 17,1972 , at 2, col. 7, at 4, col. 7 , at I4, col. 7, at I5, col. I; Aug. 3, r972, at ro, col. I; Aug. ro, 1972, at 10, col. x. Many of the concerns of the anti-marketeers about the Community institutions imposing their will on Parliament in the future were clearly without foundation inasmuch as Community regulations are adopted only after wide-ranging consultation with the staff of the diplomatic representatives of the member states in Brussels (The Committee of Permanent Representatives) and determined opposition by a member state would scuttle any Commission proposal for a regulation. As far as Community directives are concerned, they require national legislative action for implementation and thus Parliament's prerogatives will be fully safeguarded.

${ }^{18}$ Cf. A. Dicey, Introduction to tFe Study of THE LAW of the Constitution $64-85$ (roth ed. 1959).

${ }^{19}$ See Mitchell, "What Do You Want to be Inscrutable For, Marcia?", 5 CoMM. Mkr. L. REv. I12, II 8-20 and notes accompanying (I967) [hereinafter cited as Mitchell].
} 
Parliament from legislating in the future for the members of the Commonwealth. Although this type of limitation is essentially territorial, Mitchell contends that "there is no logical reason why another form of [self-] limitation, i.e., one on legislative content, should not also be acceptable where coupled with a transfer of matching legislative capacity."20 If one were to agree with Mitchell's argument, the stability of the legal situation following Parliament's approval of British accession to the Communities would be largely assured.

It seems, however, that the limitation theory of parliamentary sovereignty is not generally embraced. During the debates on the possibility of accession to the Community in the House of Lords in I 962 the Lord Chancellor stressed that an Act of Parliament enacted to apply the Community treaties in the United Kingdom could be repealed by subsequent legislation because "Parliament's power cannot be fettered."21 Nevertheless, the Lord Chancellor admitted, such legislative action would be a breach of the international obligations assumed in the accession agreement which could be justified only in exceptional circumstances or with the approval of the other member countries. In fact, it may well be one of the unwritten conventions of the British constitution that Parliament must not pass legislation which is inconsistent with the international treaty obligation's of the United Kingdom. Under international law such an act would be illegal and a denunciation of the treaty although, if passed by Parliament, it would have to be enforced by the British courts. In order to prevent the occurrence of such a calamity through carelessness, bills presented to Parliament are painstakingly scrutinized for terms inconsistent with international obligations. Therefore there is at least little chance that a bill may be passed unintentionally to upset the full application of the accession agreement as translated into law through previous Parliamentary action.

II

\section{The Impact of Community Law on the Brittsh Legal System and Judictary Procedures}

\section{A. Impact on Substantive Law}

The White Paper, The United Kingdom and the European Communities, of July I97r, declares ${ }^{22}$

The English and Scottish legal systems will remain intact. Certain provisions of the [Community] treaties and instruments made under them, concerned with economic, commercial and closely related matters, will be included in our law. The common law will remain the basis of our legal system, and our courts will

${ }^{20}$ Id. at 120. Mitchell, British Law and British Membership, 6 EuROPAREchr 97 (I97I), presents the same analysis deepened to include political aspects and strengthened. See also Thompson \& Marsh, The United Kingdom and the Treaty of Rome: Some Preliminary Observations, II INT'I \& CoMP.

L.Q. 73 ( 1962 ) [hereinafter cited as Thompson \& Marsh].

243 PARL. DEB., H.L. (5th ser.) 422 (I962). (I97I).

Cabinet Office, The United Kingdom and the European Communities, Cmnd. No. 47I5, at 9 
continue to operate as they do at present. In certain cases, however, they would need to refer points of Community law to the European Court of Justice.

This statement reaffirms, as already recognized by the 1967 Command Paper 3301 on Legal and Constitutional Implications of United Kingdom Membership of the European Communities (par. 23), the constitutional precedents regarding international treaties imposing restraints on national laws inconsistent with the treaty provisions-for example, the European Convention on Human Rights and GATT. The fields covered by the Community treaties are indeed functionally limited and mainly confined to the economic sphere. As a consequence, British and Scottish criminal law, the law of contract or torts, property law, the relations between landlord and tenant, town and country planning law, matrimonial law, and the laws of inheritance will generally not be affected by Britain's entry into the Community.

The particular fields in which Community law is likely to have an immediate, direct impact on the British legal system will be antitrust rules, the movement of workers and social security of migrant workers, agriculture, the regulation of coal, steel, and nuclear energy industries, and perhaps transport. In the first three fields a large number of far-reaching subordinate regulations have been issued by the Community authorities many of which impose directly binding obligations and create rights for Community residents. At the same time, a growing body of jurisprudence by the Community and national courts has evolved dealing not only with the intricacies of the Community regulations, but the relationship between Community and national law. This jurisprudence is likely to become especially crucial in the field of anti-trust law where Community and national rules can be applied concurrently. ${ }^{23}$ The fitting of the British Restrictive Trade Practices Act of $1956^{24}$ into the complex legal Community framework-the European Communities Bill devotes a special section to this matter (cl. Io)-will without doubt raise many questions which will require thoughtful answers.

The free movement of workers within the Community, one of the principal aims of the EEC Treaty, may also raise legal problems in Britain. Article 48 of the Treaty declares that the free movement of workers "shall include" the right of any national of the member states to accept an offer of employment anywhere in the Community. Under the British Nationality Act of I948 there is a dual system of British citizenship. Each of the self-governing dominions and the United Kingdom and Colonies have their own citizenship, but citizens of any one of the countries are also considered "British subjects" or "Commonwealth citizens."25 What then is the meaning of "national" in this context?"26 Does Article 48 confer a general

\footnotetext{
${ }^{23}$ Cf. A. Green, Political Integration by Jurisprudence 336-46, 255-90 and cases discussed thercin (I969). See also D. Mclachlan \& D. Swanson, Compettiton Policy in the Europenn Community (I967); E. Stein \& P. HAy, LAW and InstTtutions in the AtLantic ARea 5I7-714 (1967).

2* 4 \& 5 Eliz. 2, c. 68.

25 II \& 12 Geo., c. 56.

${ }^{28}$ EEC Treaty, art. I35 requires special agreements among member states with respect to the frec movement of workers who are citizens of dependent territorics.
} 
right of immigration? The White Paper on British Entry ${ }^{27}$ states that the definition of nationality is being discussed with the Community and that the Community's regulation will not affect British control over immigration from countries outside the Community. However, this interpretation' may not preclude future disparities in this important area of public law. ${ }^{28}$

The European Communities Bill provides general authority in' Clause 2 for the accommodation of Community law in the fields listed above. Special sections are devoted to the administration and financial adaptation to the Community's Common Agricultural Policy (CAP) (cl. 6) and to the payments of social security benefits outside the United Kingdom in connection with the movement of persons within the Community (cl. 2[2]).

The power conferred on the Community institutions to issue subordinate regulations which take effect directly as law within the member states, and directives which may impose obligations on these states to take certain actions are novel features in international treaties setting up regional organizations. Moreover, the Community institutions are authorized to administer and enforce, subject to the control of the Community Court, much of the law deriving from the Community treaties and the instruments made under them. Clause 3 of the European Communities Bill facilitates such proceedings by specifying the legal treatment (validity, meaning, and effect) and proof of Community instruments.

At times it is not easy to determine whether a provision of the Community treaties is self-executing, as quite obviously are the antitrust clauses of the EEC and ECSC Treaties, ${ }^{29}$ or whether a provision merely sets up an objective agreed upon by the member states, leaving it to them to achieve these objectives by either legislative or administrative action'. The progressive liberalization of capital movement between member states is one example. ${ }^{30} \mathrm{~A}$ number of decisions of the Community Court have addressed themselves to this problem. The pronouncements of the Court have been at times somewhat ambiguous ${ }^{31}$ and there is little doubt that more questions on this difficulty will be raised in the future in which British legal problems may well be involved.

\section{A. The Harmonization of Laws}

One of the most important aspects of the EEC. Treaty is the provision for harmonization of certain fiscal and economic laws in the member states. Without

\footnotetext{
${ }^{27}$ CMND. No. 47×5, supra note 22.

${ }^{28}$ See Thompson \& Marsh, supra note 20 , at $82-84$, for other legal aspects of this issue.

${ }^{20}$ EEC Treaty, arts. 85, 86; ECSC Treaty, arts. $65,66$.

${ }^{30}$ EEC Treaty, arts. 67, 68.

${ }^{31}$ The Court has held that articles $x 2,37,53$, and to some extent $95(\mathrm{I})$ of the EEC Treaty are selfexecuting. N. V. Algemene Transport-en Expeditie Van Gend \& Loos v. Netherlands Fiscal Adm'n, 9 Recueil de la Jurisprudence de la Cour I (Cour de Justice de la Communité européenne 1970) [hereinafter cited as Recueil de la Cour], [Court Decisions I96r-I966 Transfer Binder], CCH Comm. Mkr. Rep. I 8008 ( 1963 ). Costa v. Ente Nazionale Per l'Energia Elettrica (E.N.E.L.), Io Recueil de la Cour rr4I, [Court Decisions I96r-rg66 Transfer Binder] CCH CoMM. MKT. REP. ๆ 8023 (1964). For a discussion of these and other cases, see A. GrEEN, supra note 23, at 319-46.
} 
such harmonization the proper functioning of the Common Market would be endangered an'd the ultimate goal of the Treaty, the creation of an economic union, placed in doubt. Article 99 of the EEC Treaty insists on the harmonization of turnover taxes, excise duties, and other forms of indirect taxation. Article ror stresses the need for the harmonization of legislative or administrative provisions of the member states which might distort the conditions of competition in the Common Market. Finally, Article roo provides the legal basis for the "approximation of such legislative and administrative provisions of the Member States as have a direct incidence on the establishment or functioning of the Common Market."32

For the implementation of the above provisions the Council of Ministers, acting by unanimous vote on proposals of the Commission, can issue the necessary directives. When the disparity between legislative and administrative provisions of the member states distorting the conditions of competition cannot be resolved through consultation, the Council can issue the necessary directives by a qualified majority vote. However, the power conferred by Article ror has not been used. As for new distortions resulting from the introduction of changes in the national legal systems, Article ro2 establishes a procedure to prevent such occurrences.

Another provision of the EEC Treaty aiming at the harmonization of national laws is Article 220. This article requires member states to enter into negotiations with each other to eliminate double taxation within the Community, to ensure the mutual recognition of companies of different member states, to safeguard their headquarters from one country to another, and simplify in a uniform manner the reciprocal recognition and execution of judicial decisions.

Progress in the harmonization of laws so far has not been' spectacular. Fiscal harmonization has been enhanced through the introduction of similarly constructed added-value taxes in all member states except Italy. The Italian government has promised to follow suit on January I, I973. However, the tax rates in the member states are not uniform and until this uniformity has been achieved, the movement of goods across the borders inside the Common Market encounters delays. Some progress has also been made with respect to differing national taxes and tax rates applicable to mergers as well as with the double imposition' of taxes on company headquarters and subsidiaries located in different EEC countries. However, the national governments of the member states have expressed a variety of reservations and therefore full harmonization is not in sight. In the pharmaceutical sector, the Council of Ministers adopted in 1965 a harmonization directive proposed by the Commission, but some of the member countries have failed to implement this directive so far. National laws setting technical standards for industrial products also have constituted serious obstacles for the proper operation of the Common

\footnotetext{
${ }^{32}$ Although the Treaty employs the terms "harmonization" and "approximation," the two terms do not denote different meanings. Cf. E. STEIN \& P. HAY, supra note 23 , at 776 . The Treaty also contains some clauses detailing specific cases for harmonization. See, e.g., EEC Treaty, arts. 54(38), $56(2), 57(2)$.
} 
Market. Some proposals for eliminating the disparities in national laws have been accepted by the Council of Ministers and some implementation has been initiated.

The slow implementation of the harmonization directives and proposals stems from opposition by special national interest groups and from the general inertia of the national bureaucracies which ten'd to resist any kind of change which may impinge on their administrative and policy discretion. An excellent example is the endeavor to create a common European company law either through a Common Market-wide statute or through parallel national legislation. One major stumbling block for harmonization in this very important field is the insistence of German trade unions and consequently the German government on the inclusion of co-determination rights of labor similar to or more extensive than those existing in the Federal Republic. This is strongly resisted not only by industrial groups in other member states but even by organized labor in Italy. More successful have been the efforts made toward the establishment of a European' patent law which are based on Article 220 and which have resulted in an initial European draft convention on this matter covering not only the Common Market but other West European countries as well..33 Finally, under the same article the Six have negotiated a Convention on jurisdiction and enforcement of judgments in civil and commercial matters. This convention is designed to lead to almost automatic recognition and enforcement throughout the the Community of judgments given in any member state. Article $\sigma_{3}$ of the Convention requires acceptance by any future member of the Community and therefore this document is of vital interest to the British legal system. The process of ratification has been set in motion by the governments of the Six and, therefore, appropriate negotiation's by Britain with respect to this conveniton must be conducted. ${ }^{34}$

The European Communities Bill introduced into the British Parliament contains specific provisions designed to enhance the process of harmonization with respect to company laws (cl. 9). Other harmonization measures can be taken under the general provisions of this bill. ${ }^{35}$ As for the added-value tax, the I97r budget of the Chancellor of the Exchequer announced the introduction of such a tax system in the United Kingdom for I973. Thus the base is set for a broad harmonization of important fiscal and economic laws on an almost Western European-wide basis. However, Great Britain and the other applicant countries need to catoh up first with the harmonization level achieved so far by the original Common Market countries and it is difficult to anticipate vast progress beyond that level until the latter part of this decade or perhaps the $I 980$ 's.

\footnotetext{
${ }^{33}$ W. Feld, Transnational Bustness Collaboration among Common Market Countries $67-76$ (1970); E. Stein, Harmonization of European Company Laws (197x), especially $488-97$.

${ }^{34}$ For details, see Newman, Jurisdiction and Recognition of Judgments Throughout the Common Market, in International Conference on the Expansion of the European Communities, Legal Problems of and Enlarged Europen Community (M. Bathurst ed. I970) (The British Institute of Int'l and Comp. Law Studies in int'l and comp. law, no. 6).

${ }^{\text {s5 }}$ See also Mitchell, supra note 19, at I23-24.
} 


\section{B. The Role of the British Courts}

The structure of the Community Treaties and of the regulations and other instruments issued by the authorities of the Communities differs from that of statutes and subordinate legislation in the United Kingdom. The provisions of the former are framed in more general terms and more is left to judicial interpretation. For this reason the interpretation of law emanating from the Communities is likely to present some problems to the legal profession and, so far as it falls within their jurisdiction, to the courts of the United Kingdom. Although the task of construing international treaties given the force of law in the United Kingdom is not a new one, this function is apt to expand considerably as courts are faced with a growing number of cases arising from Community law and subordinate ordinances. On the other hand, after Britain's entry into the Community, British legal experts will be taking part in the preparation of future Community regulations and thereby the special needs an'd style of the British legal system can be taken into account.

There is no doubt that British lawyers will have to learn some of the principles of public and administrative law which have become part of the legal system embodied in the Community law and which have been interpreted by the Community Court against the background of the legal systems prevailing in the original six member states. This learning process may well have a far-reaching impact upon the evolution of law and its practice in the United Kingdom. As Mitchell points out, once lawyers understand what remedies they can have against Community actions and institutions, they are likely to start asking why they should n'ot have the same remedies against the public acts of their own governments. ${ }^{36}$

Another legal dimension of importance for the British legal system stems from the responsibility of the Commission to enforce Community law. The Commission, under the EEC and ECSC Treaties, ${ }^{37}$ has in some cases the power to decide whether there has been an infringement and may impose penalties in accordance with a quasi-judicial procedure. We should note that these penalties under the two treaties are almost always monetary. ${ }^{38}$ The decisions of the Community institutions, however, are subject to challenge before the European Community Court and the imposition of a penalty is invariably subject to a right of appeal to the Court. ${ }^{30}$ The European Communities Bill has taken these powers of the Commission and the Court into consideration' and makes it a criminal offense to give false evidence under oath before the Community Court ( $\mathrm{Cl}$. $\mathrm{II}$ ). This clause also makes it a criminal offense to disclose Euratom classified information. There seems little doubt that the

\footnotetext{
${ }^{36}$ Mitchell, supra note 19, at I22.

${ }^{37}$ Examples are Articles 3, 16, and I9 of EEC Reg. $x 7$ Implementing Articles 85 \& 86, JournaL officier des CoMmunautés Européennes, February 2I, 1962, at 13/62, CCH CoMms. Mkt. Rep. I 2401 I 2632 (1962) (The regulation on antitrust law); ECSC Treaty, arts. 36 \& 64.

${ }^{38}$ An exception exists under the Euratom Treaty where security violations may lead to prison terms (art. 145). See also Comments 2-4 to Article 172 EEC Treaty, in InTergovernmental ConfERENCE ON the COMMON MARKET and EURATOM, supra note I.

${ }^{80}$ EEC Treaty, arts. 172, I73.
} 
safeguards in the Treaty to ensure fairness and inviolability of the rights of citizens are of the same quality as found under British law.

Enforcement of decisions of the Court, the Commission, an'd the Council of Ministers imposing a pecuniary obligation is to be carried out by the national governments in accordance with the rules of civil procedure applicable in a particular member state. 'The national authorities may not question on' any ground the correctness of the decision to be enforced. Only the Community Court can suspend enforcement, although the method of enforcement and legal questions arising in the course of enforcement may be decided by national courts. ${ }^{40}$ Clause 3 of the European Communities Bill provides the necessary legislative support for enforcement actions.

In some cases the Community treaties and regulations require the member states to provide penalties under their own domestic legislation for breaches of Community law. These sanctions are usually of a civil character and the penalties provided by the national laws should be of the same character. ${ }^{41}$

In order to avoid conflicts between Community law and the national laws, the three Community treaties contain provisions to prevent different interpretations and applications of the three treaties and the quasi-legislative and other acts of the Community institutions. Under the ECSC Treaty, domestic courts must refer to the Court any case in which the validity of an act by the High Authority or Council of Ministers is contested. ${ }^{42}$ In other cases the domestic courts may interpret, without restriction, the ECSC Treaty as well as quasi-legislative and other acts of the organs of the Coal and Steel Community. Under the EEC and Euratom Treaties, domestic courts of last resort must refer all cases which require interpretation of these treaties or acts of Community agencies to the Court. ${ }^{43}$ Lower courts may also request such "preliminary decisions." The decision of the Community Court on the meaning of Community rules or actions binds the domestic court.44

The British courts, under the European Communities Bill, will be obligated under the above provisions to request preliminary rulings of the European Court on the meaning of the relevant provisions of the Treaties and their instruments and will have to apply the provisions as interpreted by the Community Court to the particular circumstances of the case before them. In particular, the Community Court under Article I77 of the EEC Treaty has jurisdiction to give preliminary rulings concerning "the interpretation of this Treaty; ... the validity and interpretations of the acts of the institutions of the Community; (and) ... the interpretation of the

\footnotetext{
${ }^{40}$ EEC Treaty, arts. I89, I92; Euratom Treaty, supra note 3, arts. I59, 164. See also Temple Lang, The Comimon Market and Common Law 28 (Ig66).

11 Legal and Constitutional Implications of the United Kingdom Membership of the European Communities, CMind. No. 3301, para. 33 (1967). Examples are EEC Treaty, art. 9r(I); Euratom Treaty, supra note 3, arts. 26, $83(3)$. Clause 2 of the European Communities Bill (Bill 68) I972 seems to apply.

${ }^{2}$ See ECSC Treaty, art. $4 x$.

${ }^{43}$ See Euratom Treaty, stipra note 3, art. I50; EEC Treaty, art. I77.

${ }^{4}$ EEC Treaty, art. 177 .
} 
statutes of any bodies set up by a formal measure of the Council, where such statutes so provide."

We should point out that traditionally domestic courts in the United Kingdom cannot engage in the interpretation' of an act of Parliament as far as it might have a bearing on that act's validity. The doctrine of the legal sovereignty of Parliament carries with it the proposition that no court can pass on the validity of a statute. This rule obviously cannot be applied to Community laws as otherwise the European Community Court would be deprived of its right under the Treaty to establish a uniform interpretation of the Treaty provisions and their subordinate instruments. Thus, the Community procedure regarding the validity of Community statutes will compel British judges to familiarize themselves with the notion of "judicial review," a time-honored concept in the history of American jurisprudence.

A considerable body of law has evolved from the submission of interlocutory questions to the Community Court under Article I77 of the EEC Treaty. Some of the landmark judgments of the Court have been issued under this clause of which the most prominent are the Van Gend \& Loos and the E.N.E.L. pronouncements in 1963 and $1964 .^{45}$ Perhaps the most famous statement of the Court on the nature of the Community law is contained in the E.N.E.L. decision:

Contrary to other international treaties, the Treaty instituting the EEC has created its own legal order which was integrated with the national order of the member states the moment the Treaty came into force and which the domestic courts have to take into account; as such it is binding upon them. In fact, by creating a Community of unlimited duration, having its own institutions, its own personality, and its own capacity in law, the right of international representation, and more particularly, real powers resulting from a limitation of competence or a transfer of duties from the states to the Community, the member states, albeit within limited spheres, have restricted their sovereign rights and created a body of law applicable both to their nationals and to themselves. The integration, with the laws of each member state, of provisions having a Community source, ... have as their corrolary [sia] the impossibility for the member states to give precedence to a unilateral and subsequent measure which is inconsistent with ... a legal order accepted by them upon a basis of reciprocity ... [T] he rights created by the Treaty by virtue of their specific original nature, cannot be judicially contradicted by an internal law, ... without undermining the legal basis of the Community. ... [A] subsequent unilateral law, incompatible with the concept of the Community, cannot prevail.40

Clearly, the last sentence of the Court's theory does not fit in with the doctrine of parliamentary sovereignty in Britain. However, as discussed earlier, the United Kingdom is obliged to hon'or the Community treaties and Community law and

\footnotetext{
${ }^{45}$ N. V. Algemene Transport-en Expeditie Van Gend \& Loos v. Netherlands Fiscal Adm'n, g Recueil de la Cour I, [Court Decisions 196I-rg66 Transfer Binder], CCH CoMm. Mḱ. REP. q 8008 (1963); Costa v. Ente Nazionale Per l'Energia Elettrica (E.N.E.L.), to Recueil de la Cour Ir4I, [Court Decisions I96I-I966 Transfer Binder] CCH CoMM. MKr. REp. \8023 (I964).

${ }^{48}$ Quoted in Feld, The European Community Court: Its Role in the Federalizing Process, 50 MiNN. L.R. 423,435 (1966). For a full discussion of EEC Treaty, art. 177, see A. GREen, supra note 23, at 16797, 3I9-4I3.
} 
therefore any unfettered exercise of parliamentary sovereignty in contravention of the Court's pronouncement would not only be a breach of international law, but perhaps also a violation of an unwritten constitutional convention.

To summarize the development of the doctrine of the Community Court with respect to cases referred to it by national courts, the following three propositions seem to be appropriate:

r. Community law and national law are two different legal orders, imposing rights and duties on individuals as well as states, and Community law and national law thus need not be consistent with each other, so that Community law need not defer to national law with respect to individual duties and rights.

2. The jurisdiction of the Court of Justice to hear cases on reference from national courts is determined exclusively by the Community Treaties.

3. The Court of Justice limits its rulings to the interpretation and validity of Community law and does not determine national law, or questions of fact, or apply Community law to the facts. ${ }^{47}$

The doctrine evolved by the Community Court in its preliminary rulings is frequently seen as an assertion of the supremacy of Community law over national law as is customary under a federal constitution. However, it may be more accurate to view the "new legal order" of the community as a mutli-layered structure in which the member states share with the Community institutions a major responsibility in the implementation of Community law. Rather than being a supreme legal system, the originality of the Community law is found in its penetration of the national legal spheres and the consequent intertwining of the two legal systems. To national law is added a European dimension, and Community law remains in many instances incomplete and ineffective without implementation by national authorities. ${ }^{48}$

Following the above line of reasoning, the restraints which the Court has placed on its power of interpretation make good sense. In keeping with these restraints, the Court may not decide whether there is a conflict of laws in a concrete factual situation and consequently which laws shall prevail in that particular situation. Moreover, the Court has no remedy to prevent the misapplication of Community law or the disregard of Community law by the national courts. This means that if a national court considers that Community law in a particular case is clear, it does not have to refer anything to the Court of Justice of the Communities. In fact, as Green points out, there are occasions when national courts are unwilling to recognize the supremacy of Community law and are astute to formulate reasons why they should not recognize this supremacy. ${ }^{49}$ Some of these courts justify their refusal to make

\footnotetext{
${ }^{17}$ A. GREeN, supra note 23, at 169 . For a full and up-to-date discussion of the Court's competences regarding preliminary rulings, see Pescatore, Interpretation of Community Law and the Doctrine of Acte Clair, Int'L Conference on the Expansion of the European Conmunities, supra note 34 .

${ }^{88}$ See the thoughful observations by Brinkhorst, Implementation of (Non-Self-Executing) Legislation of the European Economic Community, Including Directives, INT'L CONFERENCE ON THE EXPANSTON OF THE EUROpena Cosmuntries, supra note 34 .

${ }^{20} \mathrm{~A}$. GREEN, supra note 23 , at $4 \mathrm{Ir}$.
} 
referrals by finding Community law irrelevant to the decision. Other courts eliminate Community law by interpreting it away. ${ }^{50}$

Despite the earlier reluctance of national courts to refer questions to the Community Court it now appears that this reticence is slowly being overcome. Table I shows the increase of interlocutory proceedings from $196 \mathrm{r}$ to 1969 . A high-water mark was reached in 1967 and today courts in all six member states have made use of the referral proceedings under Article 177 of the EEC Treaty. ${ }^{61}$ Moreover, national courts increasingly recognize the significan'ce of Community law for the national internal legal systems and therefore a greater spirit of judicial cooperation is emerging which hopefully will be matched by the British judiciary.

III

\section{Influences of Common Law Practices on the Conmunity Court}

It may be interesting to speculate on the effects which the participation of the British judges and perhaps a British advocate-general may have on the future evolution of the judiciary practices of the Community Court. At present the procedure of the Court follows that of civil law as distinguished from the common law traditions of Anglo-Saxon jurisprudence. A case is started by filing a complaint or by reference from a national court under Article I77 of the EEC Treaty and similar provisions of the Euratom and ECSC Treaties. An answer must be filed within one month after service of the complaint and each party is allowed a second pleading (reply and rejoinder). ${ }^{52}$ The pleadings, however, are quite unlike anything in common law courts inasmuch as they are mixed documents of law and fact, including a statement of the case, a statement of the defense, proofs, and arguments on both the facts and the law.

When the pleadings are completed, the Court may take depositions, submit interrogatories, hold hearings, and request expert opinions; in general, it has full freedom, considering the motions of the parties and its own desires, to construct the n'ecessary record for a decision in the case. ${ }^{53}$ The rules of evidence differ considerably

${ }^{{ }^{0}}$ See Feld, supra note 46 , at 437 \& n. 56.

51 The French and Luxembourg courts were the last to initiate references to the Court.

\begin{tabular}{|c|c|c|c|c|c|c|c|c|}
\hline & & & Interlocutory & Proceedings & $1961-1969$ & & & \\
\hline $2 g 6 x$ & 1962 & 1963 & 1964 & $r 965$ & 1966 & 1967 & 1968 & 1969 \\
\hline I & 5 & 6 & 6 & 7 & I & 23 & 9 & 17 \\
\hline
\end{tabular}

Review of Cases Heard by the Court of Justice of the European Communimes in 1969 13 (i970) (pub. by Office for Official Publications of the European Communities).

${ }^{62}$ Protocol to the EEC Treaty: Protocol on the Statute of the Court of Justice of the European Community, April 17, 1957, CCH Comm. Mkr. Rep. 9 4731, 298 U.N.T.S. 147-156, arts. Ig(1), 20; Protocol to the Euratom Treaty: Protocol on the Statute of the Court of Justice of the European Atomic Energy Community, April 17 , 1957, 298 U.N.T.S. 256-66, arts. I9(I), 2r; Protocol to the ECSC Treaty: Protocol on the Code of the Court of Justice, April 18, 195I, 26I U.N.T.S. 247-268, art. 22(1); Rules of Procedure of the Court of Justice, CCH CoMM. MKr. Rep. $\{4751-4865$, arts. 38(I), 40(I), $4 I(I)$.

${ }^{58}$ Rules of Procedure of the Court of Justice, CCH Comm. MKT. REP. I 4751-4865, arts. 45-53. 
from those under common law since the Court has much more control over witnesses and the rules of exclusion are more restricted.

The arguments proceed in a manner very similar to that in a common law court. However, after the conclusion of the arguments of the parties, the advocategeneral presents his observations and conclusions of law which in effect constitute a recommended opinion for the judges. The advocate-general's presentation may also be considered to serve the function of the court's charge to the jury in the Anglo-Saxon system. ${ }^{54}$ With no appeal available against the Court's decision, the advocate-general's presentation may be viewed as providing at least a limited appeal stage. ${ }^{56}$

The judgments of the Court vary in form. Some follow the syllogistic pattern of the French courts, while others are in the narrative form of German, American, and British courts. In the event of differences of opinion among the judges, a vote is taken and the opinion of the majority of the judges becomes the basis for the decision. However, the manner of voting is not indicated in the published judgment and no dissenting opinions are filed. Some former judges of the Court and law professors on the Contin'ent have argued that the publication of dissenting opinions would add dignity to the Court and enhance the authority of its judgments. ${ }^{56}$ However, these arguments have not prevailed. Since it is the practice of British appeal courts to publish dissenting opinions, which indirectly also may suggest the manner of voting, the addition of British judges to the Community Court could eventually bring about a change in the present procedure.

The participation of the judges of the new member states will add three languages to the deliberations necessary for evolving a decision and thereby increase the already existing language difficulties with which the justices of the Court must cope. The deeper the knowledge of French which the new judges may have, the greater their chances of influencing the deliberation, since it has been the practice of the Court to use French as the basic working language. This, of course, may change in the future just as the presence of justices trained in common law may leave its imprint on the case law in the years to come. These opportunities to change the thrust of the Community case law may set in motion a legal learning process among judges and lawyers in the ten member states that could produce a gradual approximation of civil law and common law systems. The participation in the making of Community statutes and directives by British and Irish Common Market civil servants and legal experts is likely to subtly enhance the approximation process. As this process is supplemented by the harmonization of national laws and perhaps by the introduction of parallel legislation in the member states made necessary by the urgent demands of the forward movement of economic integration toward economic union,

\footnotetext{
${ }^{64}$ A. GREEN, supra note 23 , at 4I, 45-49.

${ }^{E t}$ For a fuller discussion of this issue, see W. FeLd, The Court of the European Communitres: New Dimension in Internattonat Adjudication IOI-04 (I964).

${ }^{\text {to }}$ See id. at 98-Ior for additional details.
} 
favorable long-range implications may ensue for the gradual political unification of Western Europe. ${ }^{57}$

\section{ConcLusion}

When, after many arduous and sometimes acrimonious deliberations, the House of Commons gave its assent to the European Communities Bill on July 13, 1972, a milestone was reached in British constitutional history. The Community law and legislation with its direct applicability for the people of Britain was accepted and the path was opened for the direct introduction of Community rules and regulations into the British legal system.

Although the opposition to British entry into the EEC in the House of Commons unsuccessfully attempted to make a last stand by moving for the adoption of a clause reaffirming the ultimate sovereignty of Parliament with respect to the Community treaties, the Solicitor General maintained that passage of the European Communities Bill was, in itself, an exercise of Parliamentary sovereign'ty. ${ }^{68}$ While the opposition's efforts were motivated, at least in part, by the hope of creating a basis for British withdrawal from the EEC at a later date, the question of such exercise of Parliamentary supremacy is likely to be moot since the increasingly close economic and political links forged between the United Kingdom and her Community partners would make the cost of withdrawing excessively high.

Considering the fact that joining the Community will undoubtedly enhance the economic and political power of Britain, one may well be justified in arguing that, at least in political terms, the decision to become a member was strengthening rather than weakening the sovereignty of Parliament. This argument was, in fact, made by the Solicitor General during the third reading of the Bill."

Moreover, the interpenetration of British and Continental legal systems caused by the continuous interactions between jurists of the various member states in elaborating new Community regulations and applying Community and other laws may serve to invigorate stale legal thinking and thereby produce desirable in'novations in the legal systems not only of Britain but of her Community partners on the Continent as well.

\footnotetext{
${ }^{57}$ Cf. id. at i15-i22. See also S. Scheingold, The Rule of Law in Polmtical Integration (1965).

${ }^{68}$ The Times (London), July 14, , 1972, at 8, col. 5.

${ }^{59}$ Id.
} 